\title{
Geohazard assessment along the road alignment using remote sensing and GIS: Case study of Taplejung-Olangchunggola-Nangma road section, Taplejung district, east Nepal
}

\author{
Dinesh Pathak \\ Department of Geology, Tri-Chandra Campus \\ Tribhuvan University, Kathmandu, Nepal \\ (Email: dpathaktu@gmail.com)
}

\begin{abstract}
Landslides and roadside slope failures resulting in road blockage, damage and economic losses are regular phenomena in the mountain regions of Nepal. Road construction in the northern belt of Himalaya is a challenging task, mainly due to the anticipated geohazard in the region and remoteness of the area. The situation is often intensified in the region due to limited engineering geological and geotechnical information. The geodisaster risk further increases due to road construction. Geohazard assessment is prerequisite to have best road alignment in mountain areas that are basically landslide-prone in many cases. The products of space science (like satellite imageries) could be a better choice for this purpose because of availability of high resolution imageries and their ready availability. The data acquired from space borne technology can be used to better assess the geological hazard condition along the road alignment. The present paper focuses to this aspect with the case study of a road section of Taplejung-Olangchunggola- Nangma, reaching the Nepal-Tibet border. The geohazard assessment along the road corridor has been carried out through extracting the relevant information from satellite images in addition to the use of available secondary information as well as field study. A GIS database has been developed with the required information, which was used to prepare various thematic layers (like geology, drainage density, slope, aspect, rainfall), followed by further analysis. The suitability of the existing alignment has been evaluated with respect to the geohazard condition along the road alignment.
\end{abstract}

Key words: Geohazard, landslide hazard map, road alignment, high altitude Remote Sensing, GIS

Received : February 10, 2014

Revision accepted: June 2, 2014

\section{INTRODUCTION}

Geohazards, their intensity, magnitude and frequency are highly variable for any combination of geo-environmental conditions in the Himalaya. Factors that control geohazards are specific for each process (e.g., landslides, floods, snow avalanches, etc.) and significant variations are observed at all spatial scales. In addition, road construction is also taking place in areas where existing geological and geotechnical information is insufficient to make decisions regarding the choice of alignments and their design. An early assessment of the potential geohazards during the planning stage would be helpful to reduce the risk (Ho and Lau 2010). The geohazards and risk are increasing in hilly and mountainous regions with the expansion of development into these areas (Hearn and Hart, 2011). In addition, geohazard condition is expected to increase in case of climate change (Pathak et al., 2010)

Geological, geomorphological and geotechnical interpretation is important on the area where land use and infrastructure planning should be done with less data (Hearn and Hart, 2011). The role of agricultural practice, construction activities and road maintenance operation on accelerating the geohazards have been discussed by many authors (e.g. Slaymaker, 2010). A better alignment can be selected if the geohazard along the route is appropriately identified. Petley et al. (2007) attributed the generally upward trend in landslide impact probably results from the rural road-building program in Nepal.

The rational for the geohazard and risk assessment while developing linear infrastructure (roads, railways, pipe lines or transmission lines) has been discussed by many authors Geohazard assessment along the road alignment is necessary also during the road operation and maintenance (Hern and Hunt, 2011) in order to reduce economic losses associated with damage and traffic delays caused by road blockages. The main reason for the losses could be inadequate assessment of hazard areas during route selection.

The road alignment under consideration in present study lies in the Taplejung districts of eastern Development Region, Nepal (Fig. 1). This road section (Taplejung-OlangchunggolaNangma) is part of the North South Corridor which starts at Kechana in Jhapa district (Indian border) and ends at Nangma (Taplejung district at Nepal-China border). 


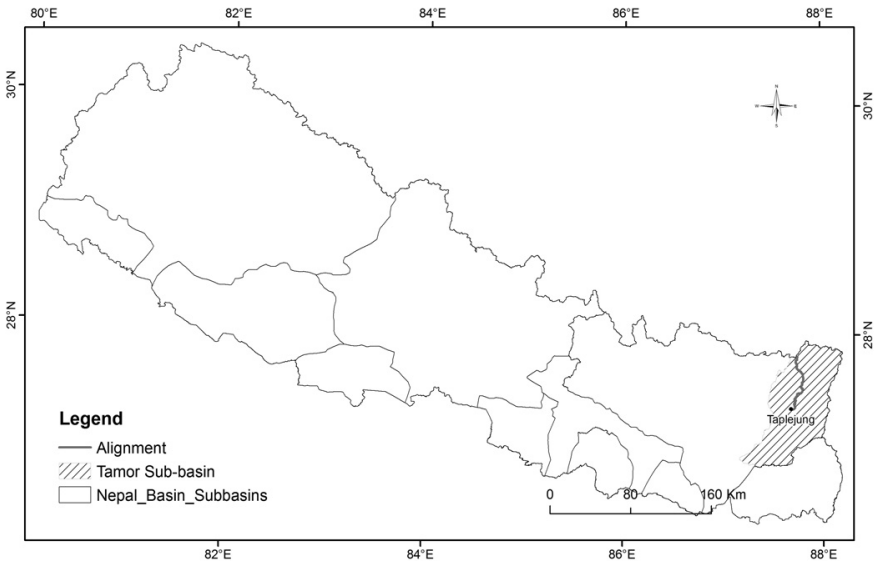

Fig. 1: Location of the road section lying in Tamor Sub-basin, considered in present study.

The $95 \mathrm{Km}$ long road section starts from Taplejung in Taplejung district and ends at Tiptala Bhanjyang at the northern border of the district is the extension of Mechi Highway H07, which is black topped up to Taplejung (Fig. 2).

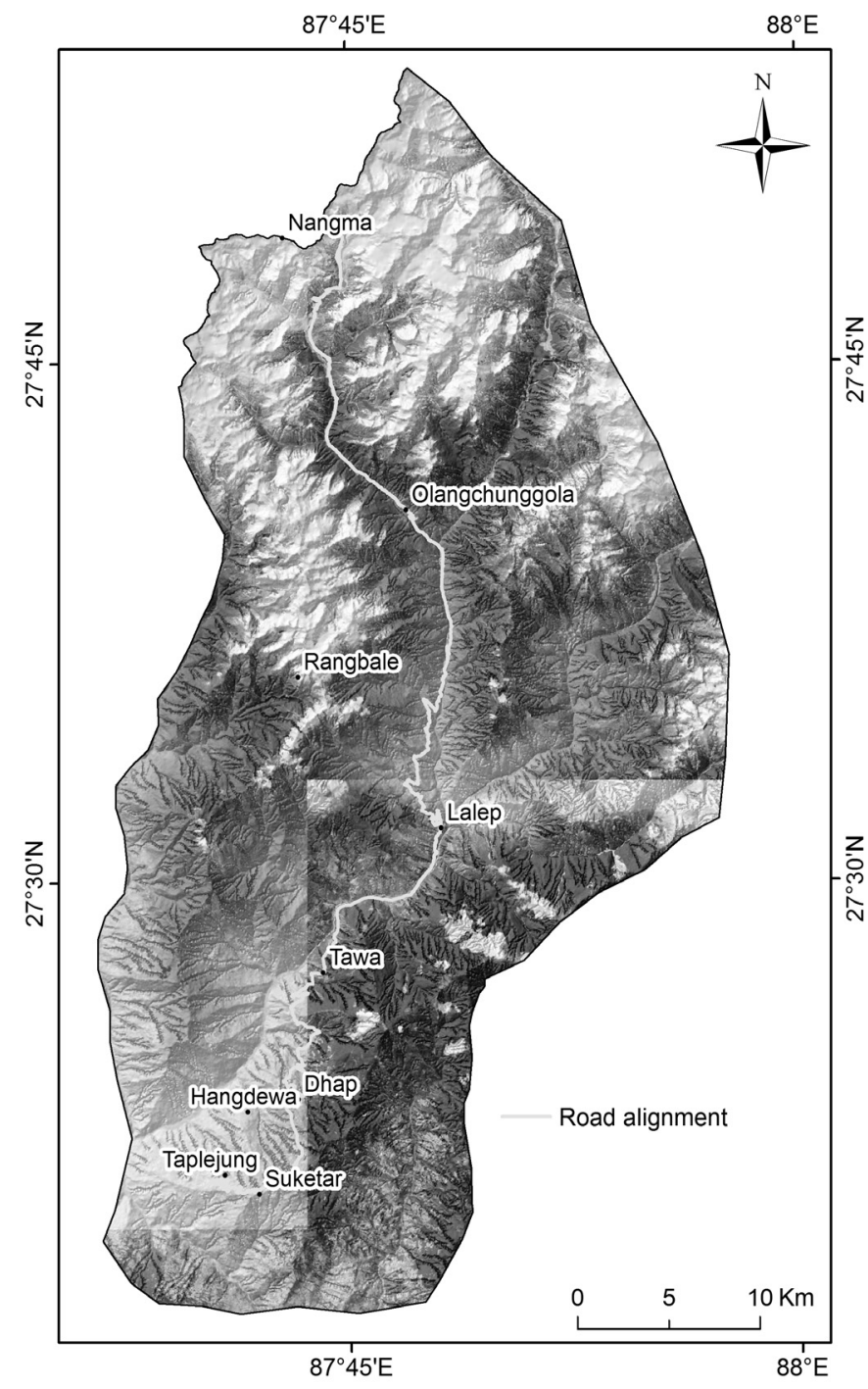

Fig. 2: The road alignment overlain on satellite image.
Track has already opened in parts of the road section while most of the road section is accessible only by foot trail at present. The road section traverses the steep and rocky terrain with narrow and deep river valleys, ranging in elevation from $1948 \mathrm{~m}$ (at Taplejung) to $4957 \mathrm{~m}$ (at Tiptala Bhanjyang, east of Nangma village).

The present study is focused to the landslides and debris flows originating on the natural slopes or drainage channel that could have possible impact to road. However, it does not consider the failures of cut slopes or fill slopes.

\section{MATERIALS AND METHODS}

The geohazard condition along the road alignment considered in this study has been assessed through the utilization of primary data collected in the field, information extracted from the satellite image and secondary information. The data used in the study are geological map of the area, digital topographic map and multi-spectral satellite imageries.

The use of satellite imageries and aerial photographs in the geohazard assessment is common nowadays (Pathak, 2014; Subramani, T. S. and Nanda Kumar, 2012.). In the present work, the satellite image of the area has been used in the extraction of relevant information like landslides, geological structures etc. Likewise, the major geodisaster sites were observed in the field.

The geological map of the area published by Department of Mines and Geology (Amatya and Jnawali, 1994; Shrestha et al., 1984) was digitized in GIS. This map consists of various geological formations with rock types and geological structures. Various thematic layers like slope, aspect, drainage density, land use, landslide distribution, physiography etc. were prepared from the digital topographic data as well as the information extracted from the satellite images. The data were integrated in GIS and bivariate statistical method was applied to prepare the landslide hazard map of the area. All these information have been used to assess the geohazard condition along the alignment.

\section{PHYSIOGRAPHY ALONG THE ROAD ALIGNMENT}

The road alignment starts from the elevation range 1000$2000 \mathrm{~m}$ and reaches to the 2000-3000 m range around Suketar then again lowers to previous elevation range after crossing the Dhap village, which continues to around Lalep village (Fig. 3). From Lalep to Okangchunggola village, it runs through the 2000-3000 m elevation range. Further northward from Olangchunggola village, it enters gradually into the higher elevation range $(3000 \mathrm{~m}-4000 \mathrm{~m})$, which continues to rise and reaches to $4000 \mathrm{~m}-5000 \mathrm{~m}$ elevation range at the end point. The road is aligned along the Tamor River northwards from Tawa village and the river valley becomes much narrow north of the Lalep village.

Physiographically, the road alignment traverses three physiographic regions, namely Middle Mountain, High Mountain and High Himalaya, from south to north (Fig. 4). 


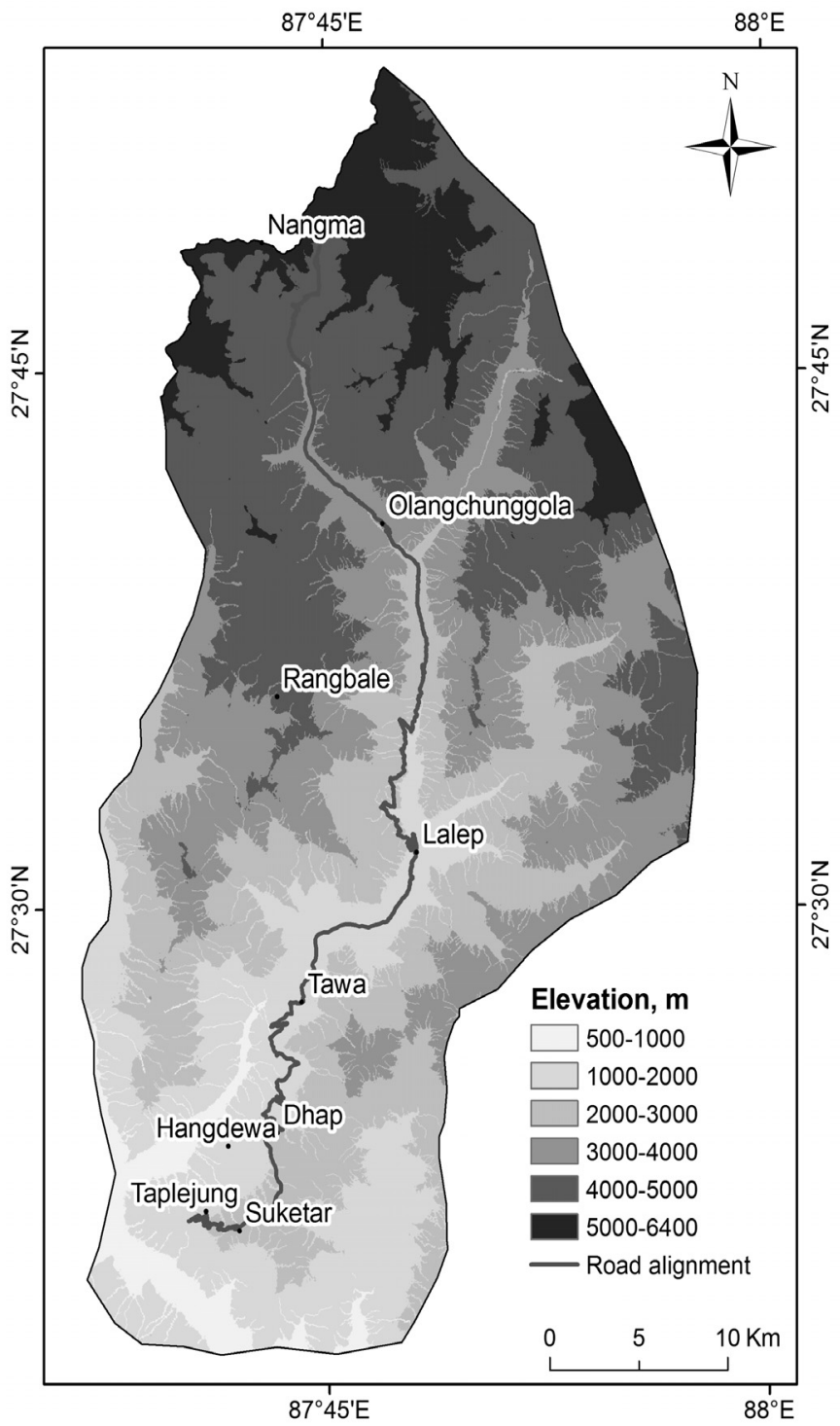

Fig. 3: Elevation ranges traversed by the road alignment.

The region south of Dhap village lies in the Middle Mountain region, between Dhap and Olangchunggola falls in High Mountain Region and north of Olangchunggola village belongs to High Himalaya region. This physiographic division well corresponds to the elevation regions discussed above. Majority of the road section falls in the High Mountain region followed by High Himalaya and Middle Mountain physiographic zone.

\section{GEOLOGIC SETTING OF THE STUDY AREA}

The entire Himalayan belt is subdivided into five laterally continuous and approximately parallel tectonic zones (Amatya and Jnawali, 1994; Shrestha et al., 1984). These are, from south to north, Indo-Gangetic Plain, Sub Himalaya, Lesser Himalaya, Higher Himalaya, and Tethys Himalaya. The study area lying in the norhtern part of the Tamor River sub-basin that covers Lesser Himalaya (Midland Group) and Higher Himalaya regions. The geological formations belonging to the Midland Group are Ulleri Formation, Kushma Formation and Seti Formation (Fig. 5).

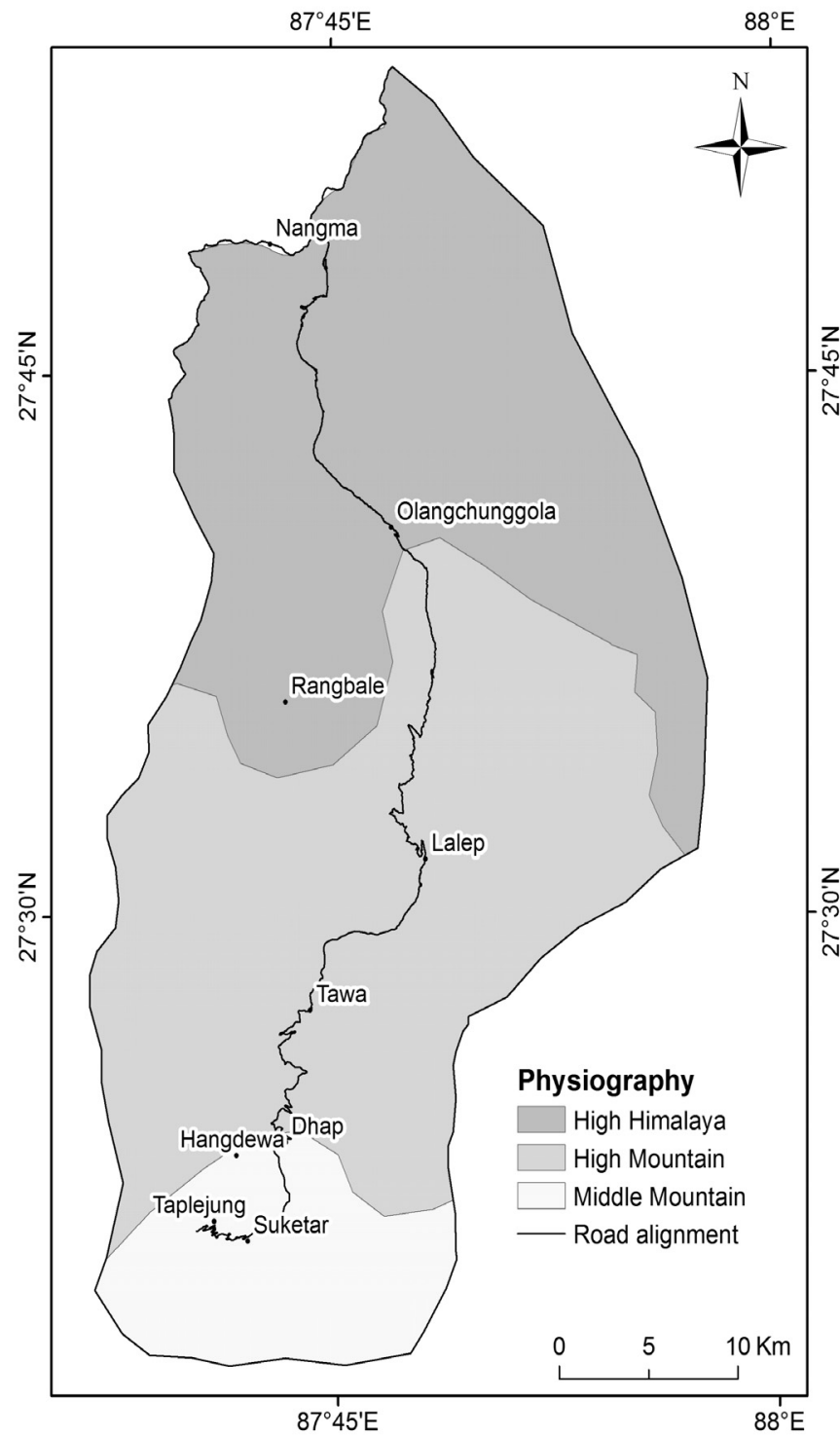

Fig. 4: Road alignment crossing different physiographic zones.

The Lesser Himalayan sequence consists of the unfossiliferous sedimentary and metasedimentary rocks like slate, phyllite, schist, quartzite, limestone and dolomite. The main rock types are feldspathic schist and augen gneiss with granitic intrusion (Ulleri Formation); greenish grey phyllite and quartzite at various proportion with some basic intrusion (Kushma and Seti Formation). The Higher Himalayan crystallines (granitic gneiss, banded gneiss, migmatites) are dominantly distributed in the northern part of the study area with granitic emplacements. The study area covers parts of the Taplejung Window, which is bounded by the Main Central Thrust (MCT) that separates the Lesser Himalaya from the Higher Himalaya.

The above mentioned geological condition greatly controls the geohazard condition in the study area. The extensively thrusted and faulted rocks give rise to steeper, unstable hill slope. The road alignment dominantly falls within the Higher Himalaya (Himal Group) and small section around Taplejung falls within the Lesser Himalayan zone. A 


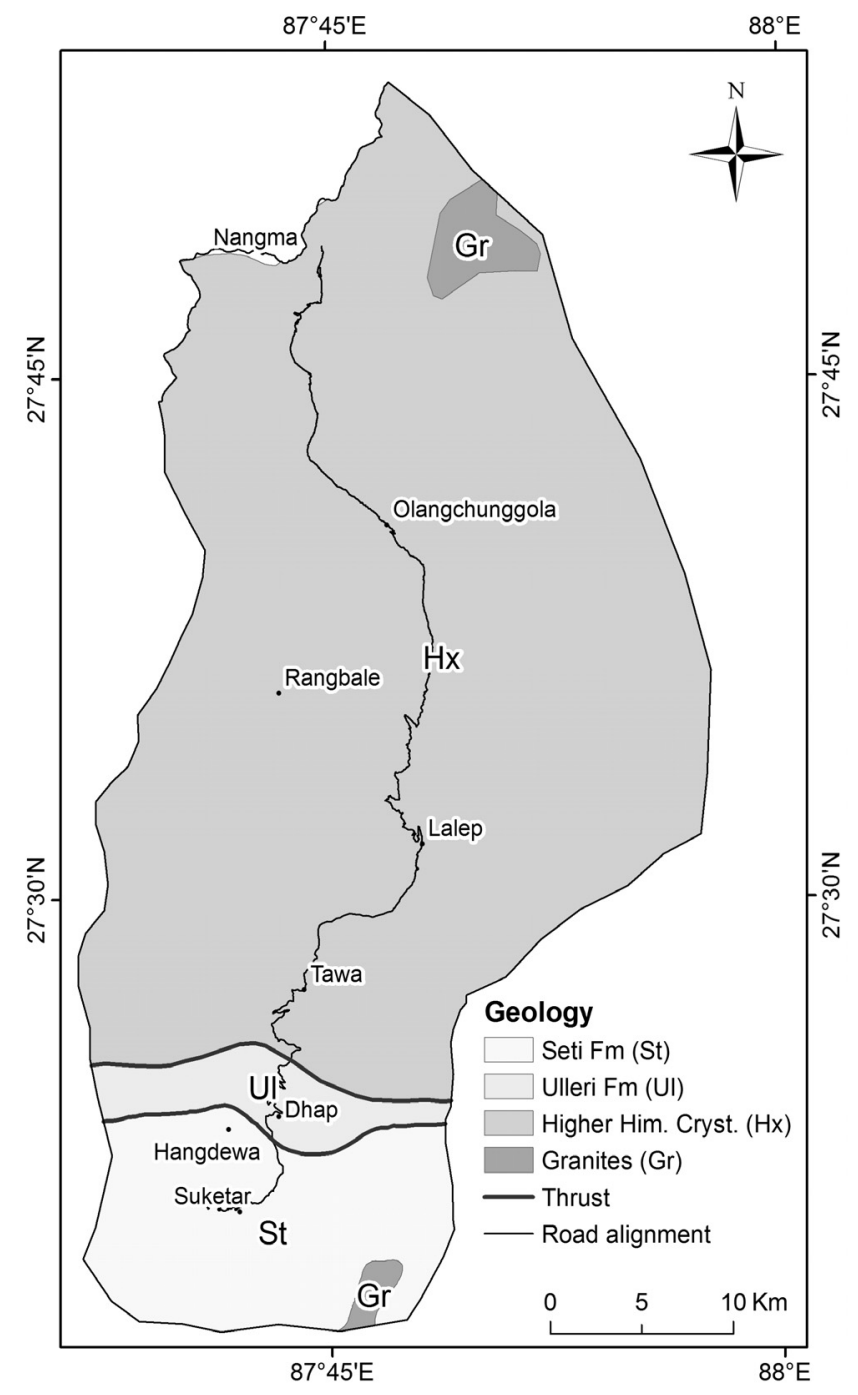

Fig. 5: Geological formations traversed by the road alignment (modified after Amatya and Jnawali, 1994 and Shrestha et al, 1984).

brief description of the different formations in and around the project area is given below:

\section{GEOHAZARD ASSESSMENT}

\section{Geohazard Assessment along the Road Alignment}

The geohazard condition along the road has been described below dividing the road at three major sections.

\section{Observation between Taplejung and Tawa village}

This road stretch extends from the Taplejung to Tawa village basically covers both the lesser Himalayan region as well as higher Himalayan region. The area between Taplejung in the south and Baisakhe village in the north falls within the Lesser Himalayan region and is characterized by the presence of phyllite and quartzite with some gneisses belonging to Ulleri Formation (Fig. 6). This area is rather critical that has many landslides, the most important being the Hangdewa landslide and Herewa landslides

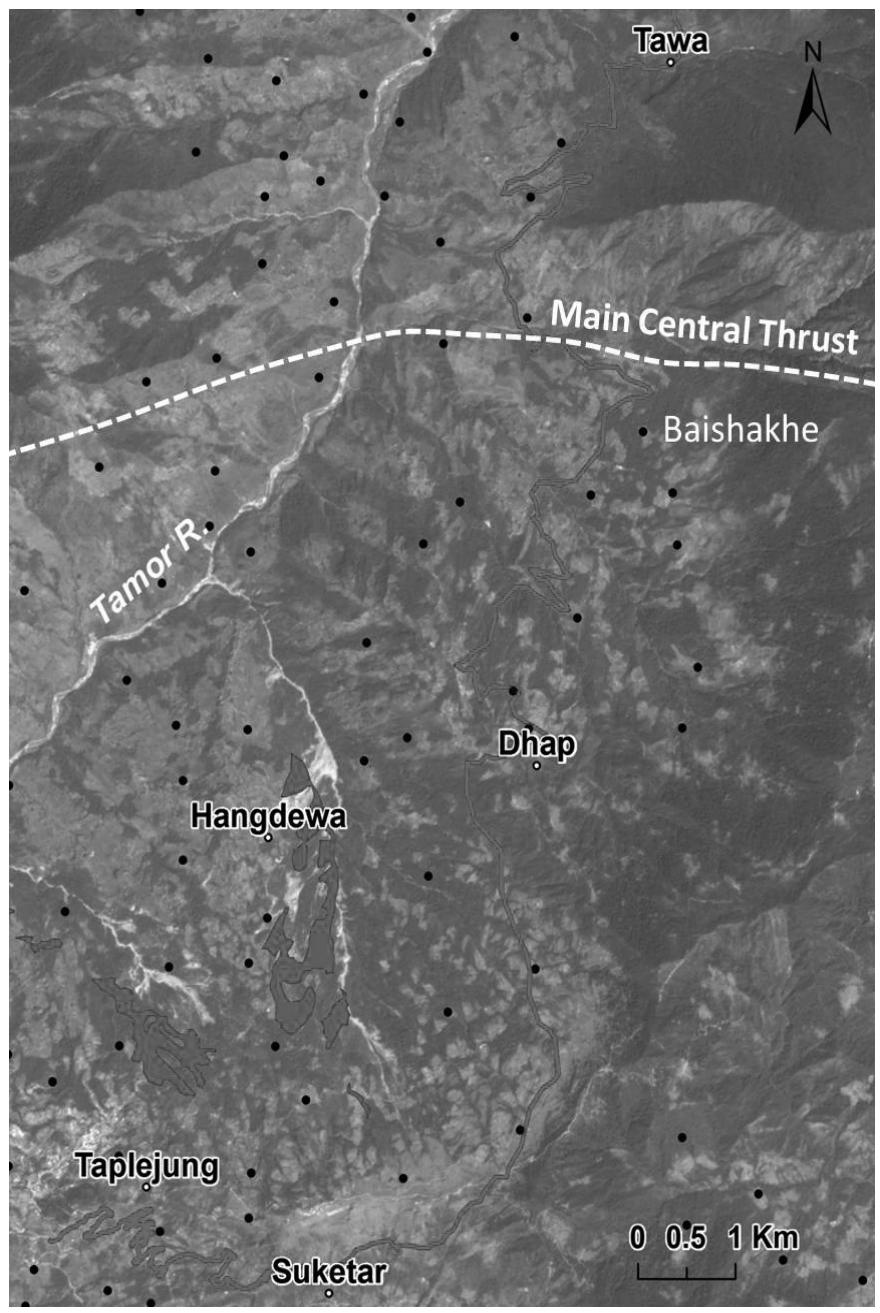

Fig. 6: The road stretch between Taplejung and Tawa village. The Hangdewa and Herewa landslides are the major slides in the west of alignment. The main central thrust (MCT) separating Higher Himalaya in the north and Lesser Himalaya in the south passes through north of Baisakhe village.

(west of Hangdewa landslide). However, these slides zones lies at the western catchment and the road stretch passes through the eastern slope, through the Suketar airport. Because of the relatively better alignment of the road that runs along the ridge area avoiding the major landslide zone, this road stretch is considered to be safe from major geological disaster.

The road crosses the major geological structure, named Main Central Thrust (MCT), north of the Baisakhe village. MCT separates the lesser Himalaya in the south and higher Himalaya in the north. At this section, unstable hill slope is expected around the MCT zone.

\section{Observation between Tawa and Olangchunggola village}

The road section between Tawa (in the south) and Olangchunggola (in the north) entirely lies in the Higher Himalayan region that consists of high grade metamorphic 
rocks, dominantly gneiss with some schists, granite, quartzite and carbonate rocks.

The road stretch between Tawa and Lalep is rather stable and no major geological hazard has been noticed except at some steeper terrain, in which the problem may arise during the road construction even though it is stable at present (Fig. 7).

The rocks around the Tansee village are light to dark grey, parallel to continuous, highly jointed, medium grained gneiss. The rocks generally dip toward NE with a dip amount of $60^{\circ}-70^{\circ}$ (Fig. 8a). The orientation of the rock discontinuities shows that thereismildpossibilityofplanefailureandwedgefailure(Fig. 8b). The area between Tansee and Nublung village is represented by light grey, thin to thick bedded, parallel and continuous, highly jointed and slightly weathered gneiss (Fig. 9a). The attitude of rocks is $135^{\circ} / 30^{\circ} \mathrm{NW}$. Widely spaced joints were observed on the rocks. The stereographic plot of the discontinuities indicates that there is moderate possibility of plane failure as well as wedge failure (Fig. 9b). The road section between Nublung village in the south and Tartong village in the north passes through some critical locations (Fig. 7). Light to dark grey, highly jointed, moderate

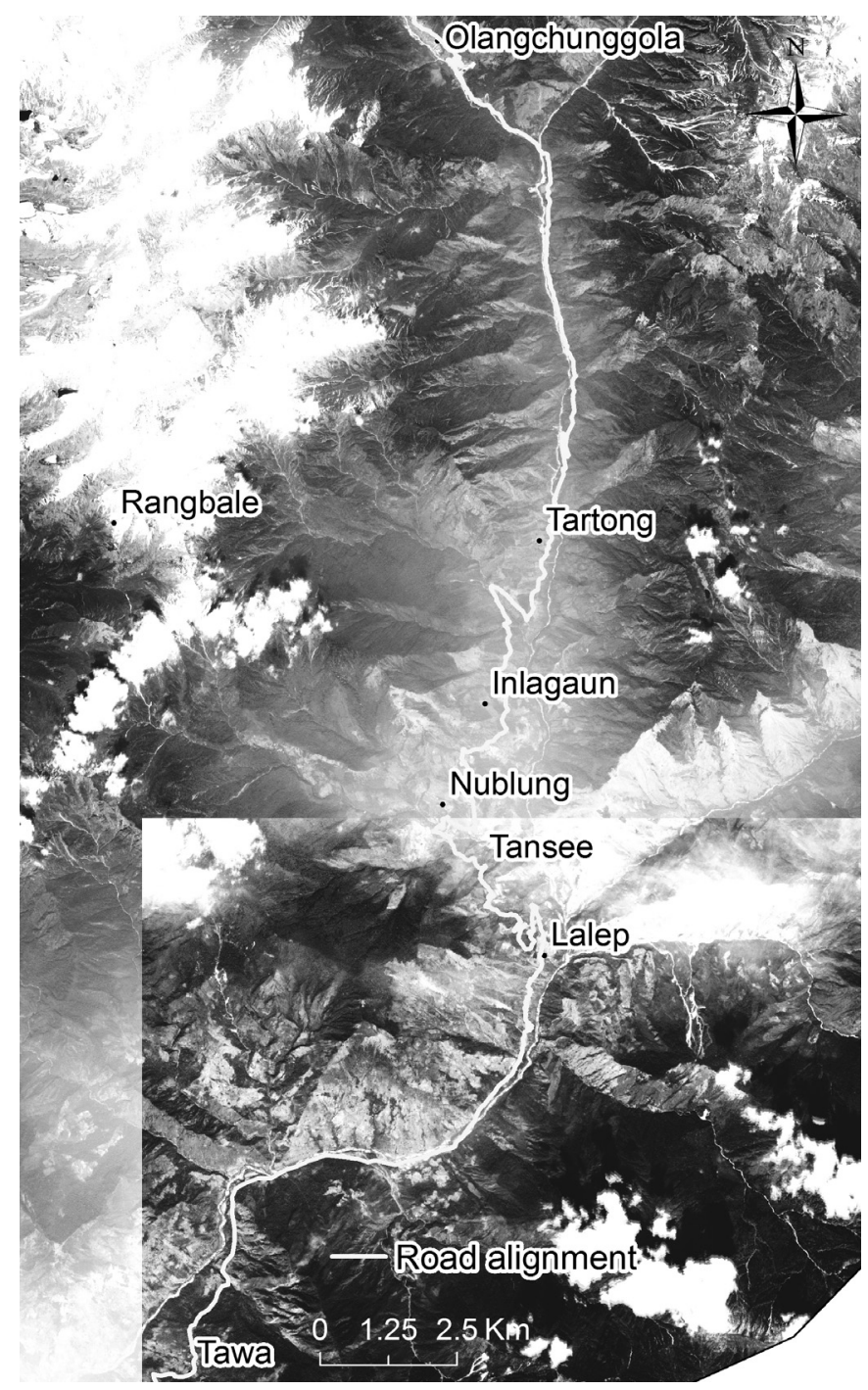

Fig. 7: Road section between Tawa and Olangchunggola village.

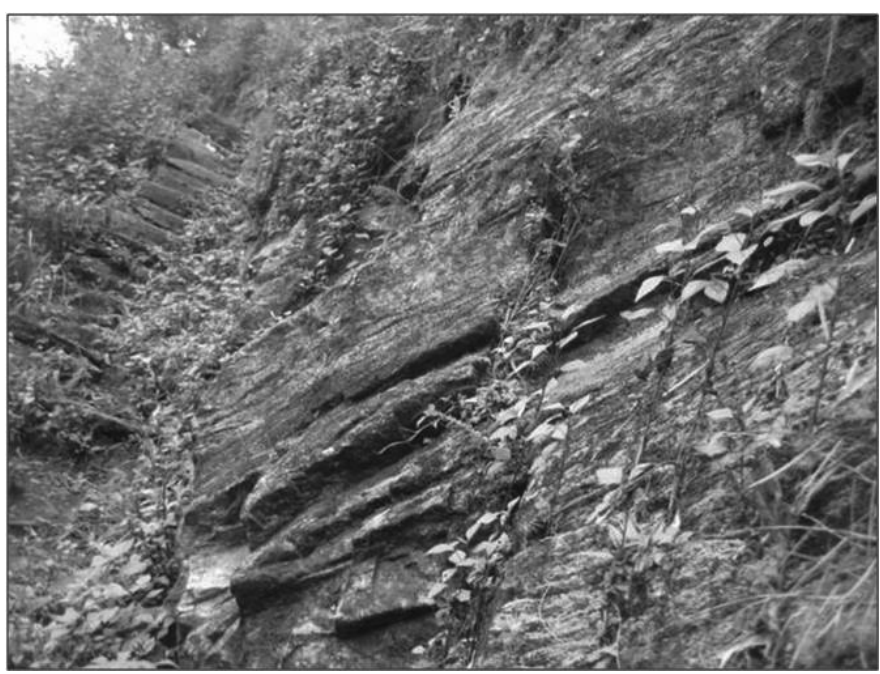

Fig 8a: Rock exposure around Tansee village.

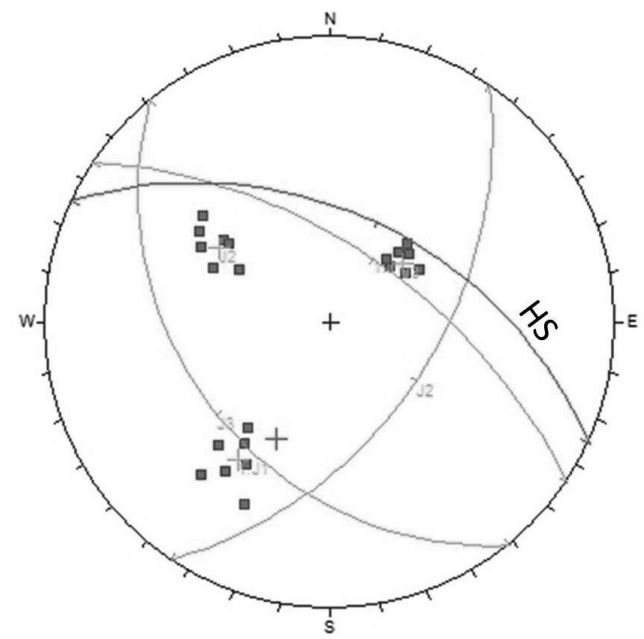

Fig. 8b: Stereo-plot of discontinuities measured around Tansee village.

to highly weathered gneiss was observed along this road section (Fig. 10a). The general attitude of the rock is $155^{\circ} / 55^{\circ} \mathrm{NE}$. The stereographic projection of the discontinuities measured on rock shows the wedge failure condition (Fig. 10b).

Observation between Olangchunggola and Nangma village

The Olangchunggola-Nangma village stretch of the road traverses typical terrain that has different climatic condition than the southern road stretch (Fig. 11).

This area mostly experiences the snow fall and hence the rocks are affected by frost action leading to physical disintegration. There are many landslides along the road alignment that is oriented in north-west direction from Olangchunggola village (Fig. 12). The active landslide is clearly visible on the satellite image near the Olangchunggola village and further northwards along the road alignment.

These landslides are principally because of the bank cutting by the Tamor River. However, few landslides also 


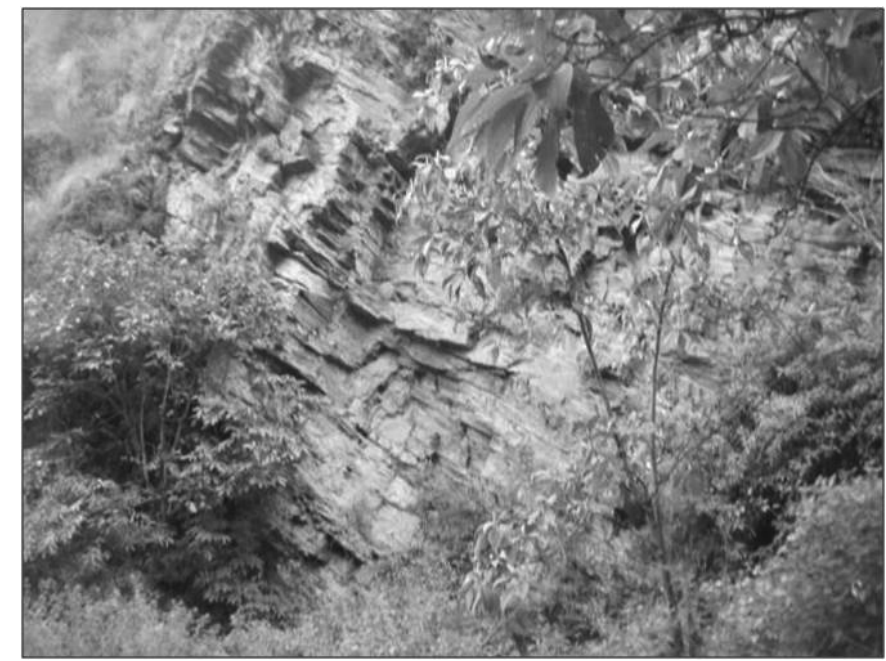

Fig. 9a: Rock exposure between Tansee and Nublung village.

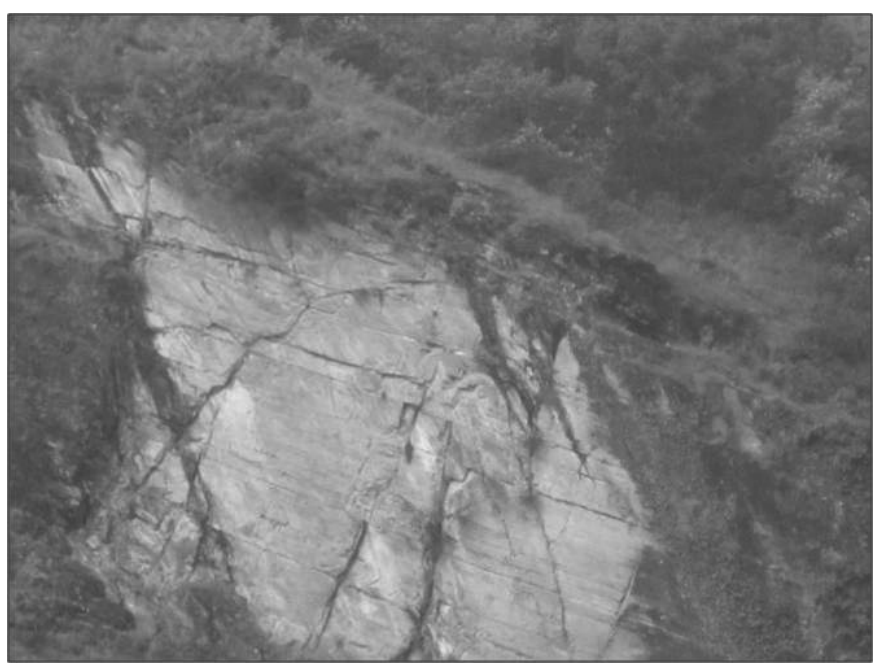

Fig. 10a: Rock cliff observed around Inlagaun.

originate from the upslope, contributing sediments to the Tamor River. The parallel streams joining the Tamor river has the potentiality to transport debris derived from the upper catchment area in eastern side of the Tamor River.

Further north of the Olangchunggola, towards the Mauma village, when the road is aligned approximately in north south direction, the hazard condition is rather complex. In addition to the presence of landslides and debris transported from the gullies, there is potentiality of the damages to be occurred due to bursting of the glacier lakes at the higher elevation at the eastern part of the Tamor catchment (Fig. 13).

The mass wasting from the upslope areas might damage the road section passing through the area. Likewise, in case of the flash flood occurring from the lake bursting, the incidence of disaster at the road section is evident. These aspects need to be considered especially across the Syamdu khola where there are larger lakes at its upper reaches. Likewise, the parallel gullies that crosses the road alignment need to be well treated for the safety of road and traffic.

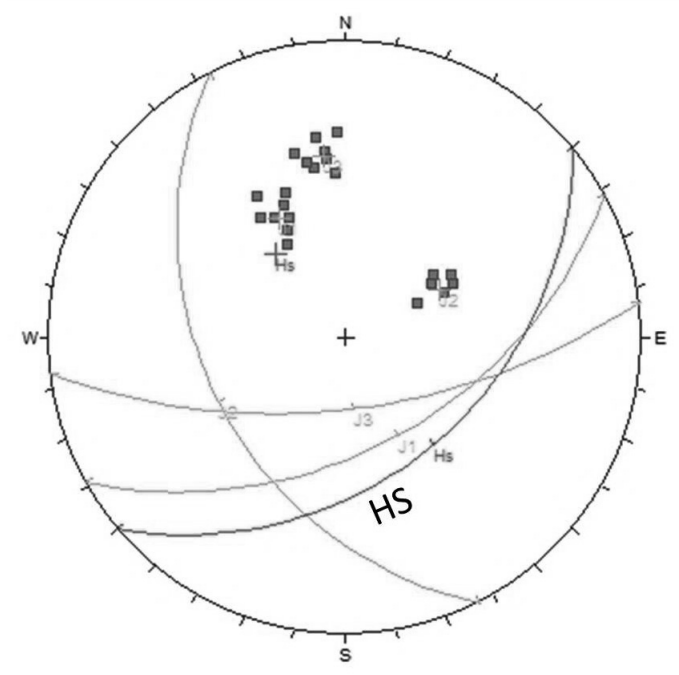

Fig. 9b: Stereo-plot of discontinuities measured between Tansee and Nublung village.

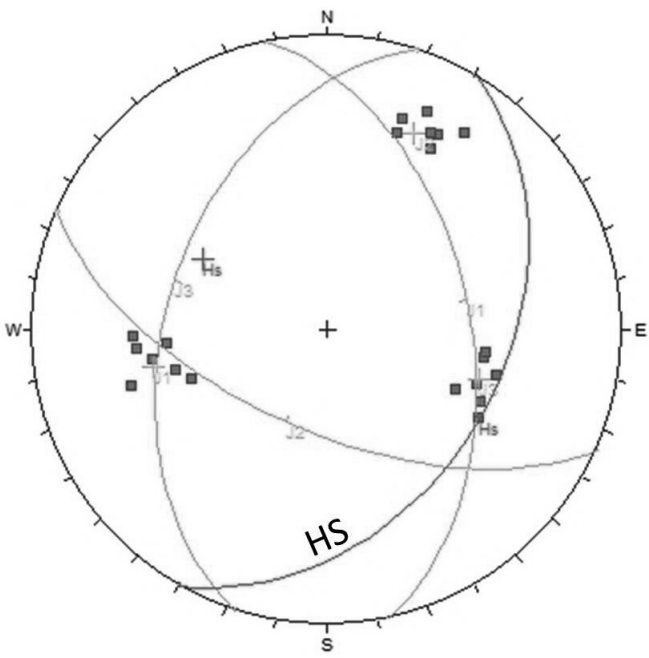

Fig. 10b: Stereo-plot of rock discontinuities measured around Inlagaun.

North of the Mauma village, up to Tiptala Bhanjyang, near Nangma village (Nepal-Tibet border), the entire road section passes through steeper slope and rocky area with thin soil cover. These areas are covered by snow during the winter. The presence of glacier lakes is also identified at the satellite image near the Tiptala Bhanjyang, east of Nangma village.

\section{Landslide hazard map of the area with the road alignment}

Landslide is a serious concern for both construction and maintenance of roads. Although the landslides are primarily associated with mountainous terrains, these can also occur in areas where excavation activities take place. Many factors contribute to landslides, including topography, geology, gravity, weather, groundwater drainage characteristics, landuse, land management and human actions. The identification of locations of active and potential landslides so as to avoid landslide prone areas, whenever possible is an important step in the planning stage of an alignment of a road. Preparing landslide inventory 


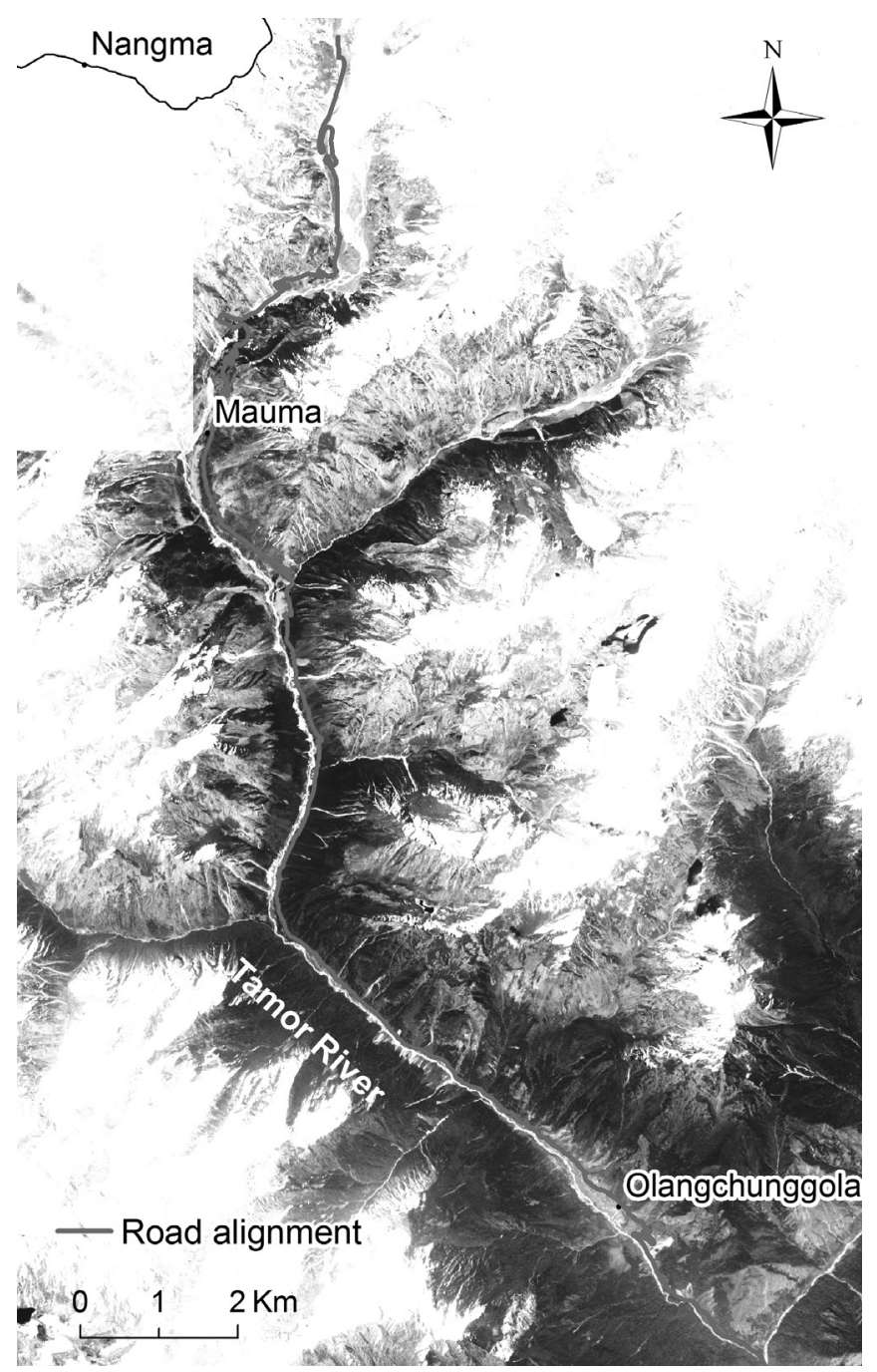

Fig. 11: Olangchunggola-Nangma road section.

database and developing landslide susceptibility map in and around the road alignment is an important step to deal with the unstable hill slopes during the road alignment selection and evaluation.

Landslide hazard maps give an indication of the probability of landslides of a given size and extent occurring over a given time, such as the design life of a road, and therefore indicate the potential to cause damage. it is equally useful to further assess the geohazard condition along the road alignment. Methods of landslide susceptibility, hazard and risk mapping are described and illustrated in numerous publications such as those by Varnes (1982), Hansen (1984), Soeters and Van Westen (1996), Aleotti and Chowdhury (1999), Guzzetti et al. (2006), Guzzetti et al., 1999; Chung and Fabbri, 2003; Remondo et al 2003; van Westen et al., 2003; Dahal et al., 2008. These models utilize the factors responsible for the occurrence of landslide. These are the causative (geology, geomorphology, slope, land use etc.) and triggering (hydro-meteorological event, earthquake, anthropogenic etc.) factors.

Landslide distribution maps depict the outline of existing landslides. The landslide inventory map has been prepared through the utilization of existing data, extraction from satellite imageries and field survey (Fig. 14).

The landslide inventory map shows that the landslides

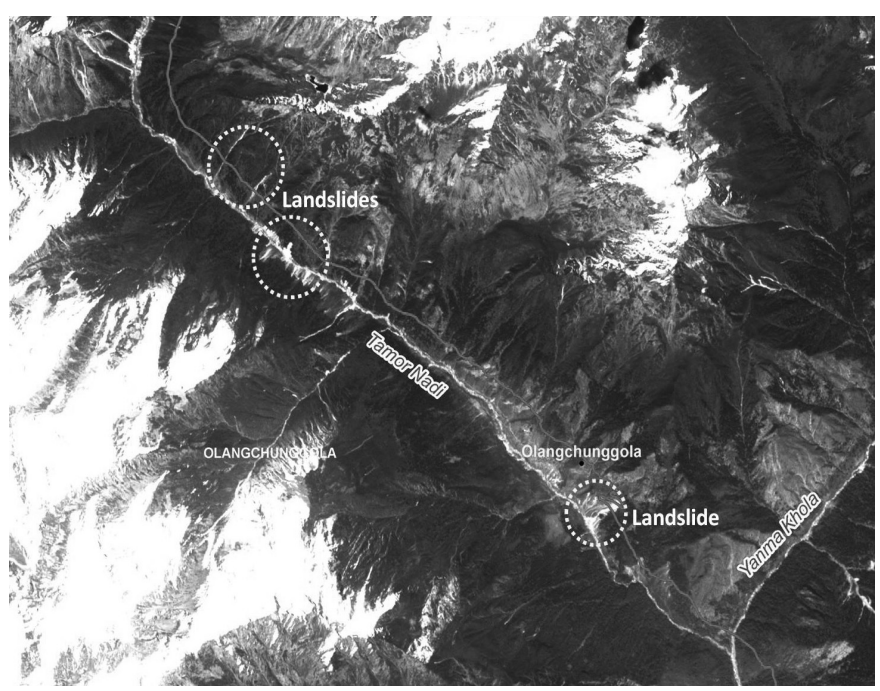

Fig. 12: Landslides around Olangchunggola and northwards along the road alignment observed on satellite image.

are distributed within the study area. The landslides at the west of Taplejung has no direct impact to road at present while the road stretch can be affected by the landslides around Lalep and Olangchunggola villages at the northern part of the road section.

Landuse is another important factor that has direct and indirect implications to the occurrence of the landslides (Glade, 2003 and Gerrard et al. 2002). The road section mostly traverses through the area covered by vegetation (tree, grass and shrubs), however, at the northernmost part of the section between Olangchunggola and Nangma village, it passes through the barren land (Fig. 15). Some of the road section

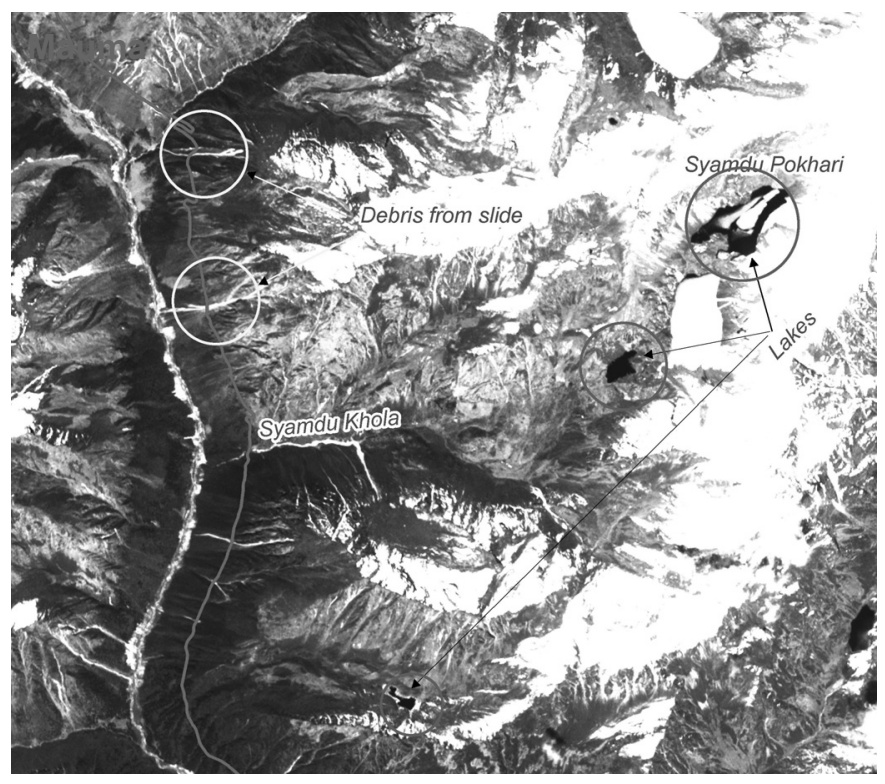

Fig. 13: Hazard condition, north of the Olangchunggola. 


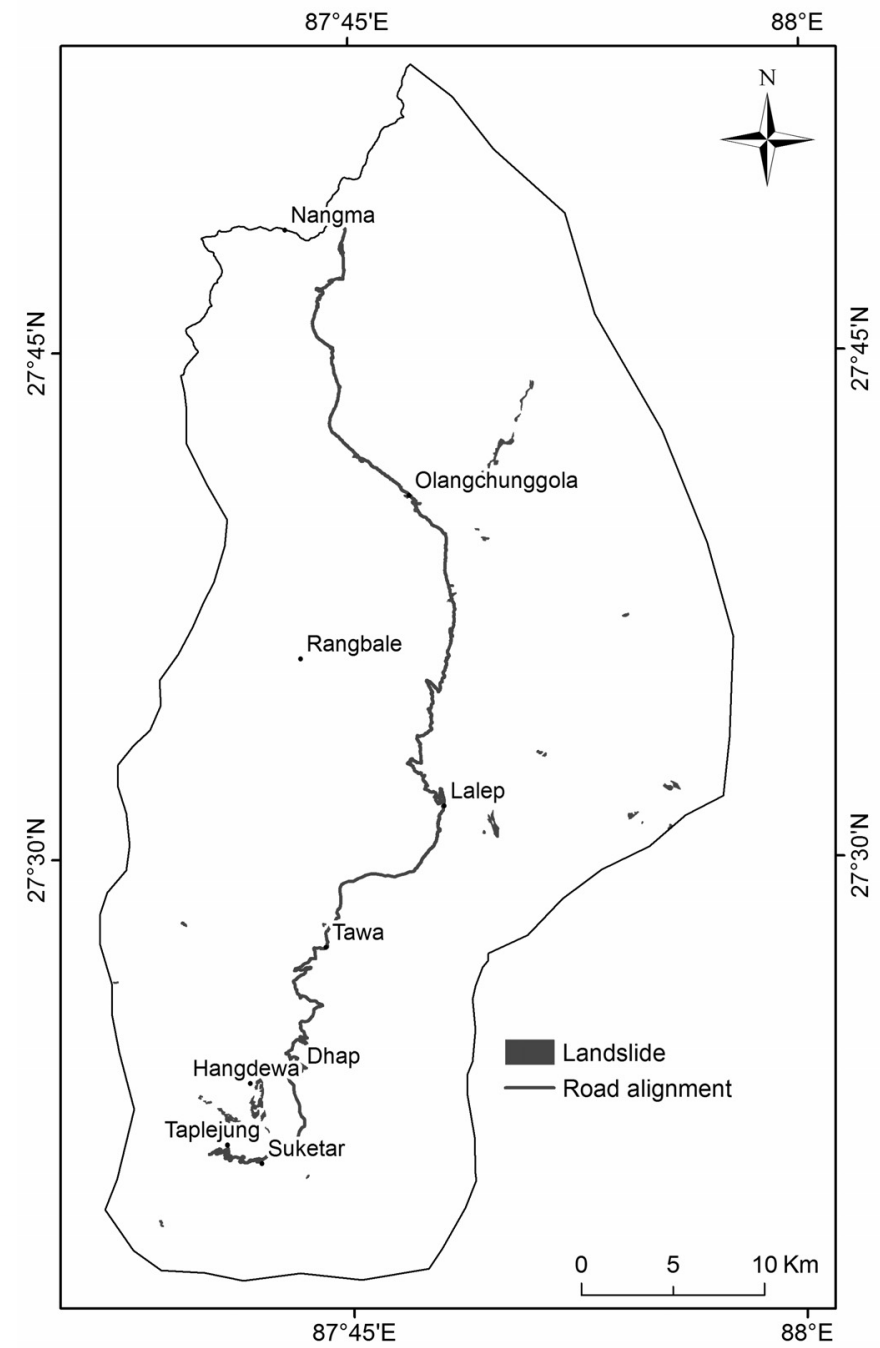

Fig. 14: Landslide inventory map at the catchment scale consisting of the road alignment.

between Taplejung and Lalep village also traverses through the cultivated area.

Various data layers like landuse, slope, aspect, geology, drainage density and rainfall have been prepared in GIS to generate landslide hazard map of the study area. In the present study, the information value method have been used to prepare landslide hazard map (Van Westen, 1997). Information Value method is one of the familiar statistical methods of landslide hazard study in the Himalaya (Saha et al., 2005). This method considers the probability of landslide occurrence within a certain area of each class of a landslide causative factor in which the weights of a particular class in a causative factor are determined from the following relationship:

$$
W_{\mathrm{i}}=\log _{\mathrm{e}}\left\{\frac{D_{\text {clas }}}{D_{\text {map }}}\right\}
$$

Where, $W_{\mathrm{i}}$ is the weight given to the all class of a particular landslide causative factor layer, $D_{\text {clas }}$ is the landslide density within the landslide causative factor class, and $D_{\text {map }}$ is sum of the landslide density within the entire landslide causative factor class layer. The contribution of each causative factor to landslide hazard have been evaluated through comparing the landslide distribution in various thematic data layers. For this purpose, the above equation can be written according to numbers of pixels as follows.

$$
W_{\mathrm{i}}=\log _{\mathrm{e}}\left(\frac{N p i x_{\mathrm{a}}}{N p i x_{\mathrm{b}}} / \frac{\sum N p i x_{\mathrm{a}}}{\sum N p i x_{\mathrm{b}}}\right)
$$

Where, $W_{\mathrm{i}}$ is the weight given to a certain parameter class (such as, a rock type or slope class). Npix is number of pixels which contain landslides, in a certain parameter class. Npix $x_{\mathrm{b}}$ is total number of pixels in a certain class in a causative factor. The natural logarithm is used to take care of the large variation in the weights.

The weights of individual classes of each thematic layers were calculated and the resulting raster maps with weights were added to produce Landslide Hazard map (Fig. 16). The landslide hazard map was validated by comparing with the different sets of landslide data that were not used in the analysis leading to generate the landslide hazard map. Thus prepared landslide hazard map, when crossed with the validating set of landslide shows that maximum number of landslide fall within the high and very high hazard classes, which is indicative of the reasonably acceptable model.

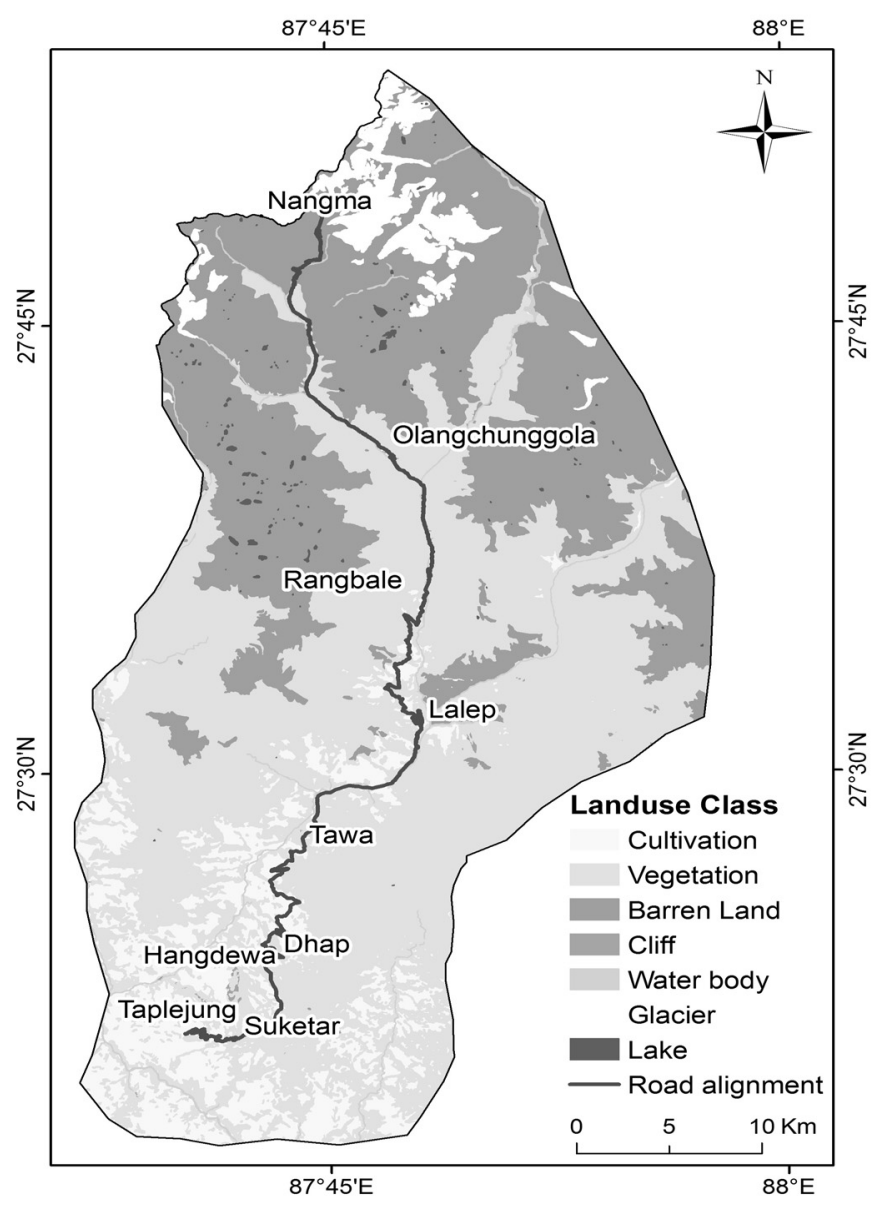

Fig. 15: Landuse map of the study area. 


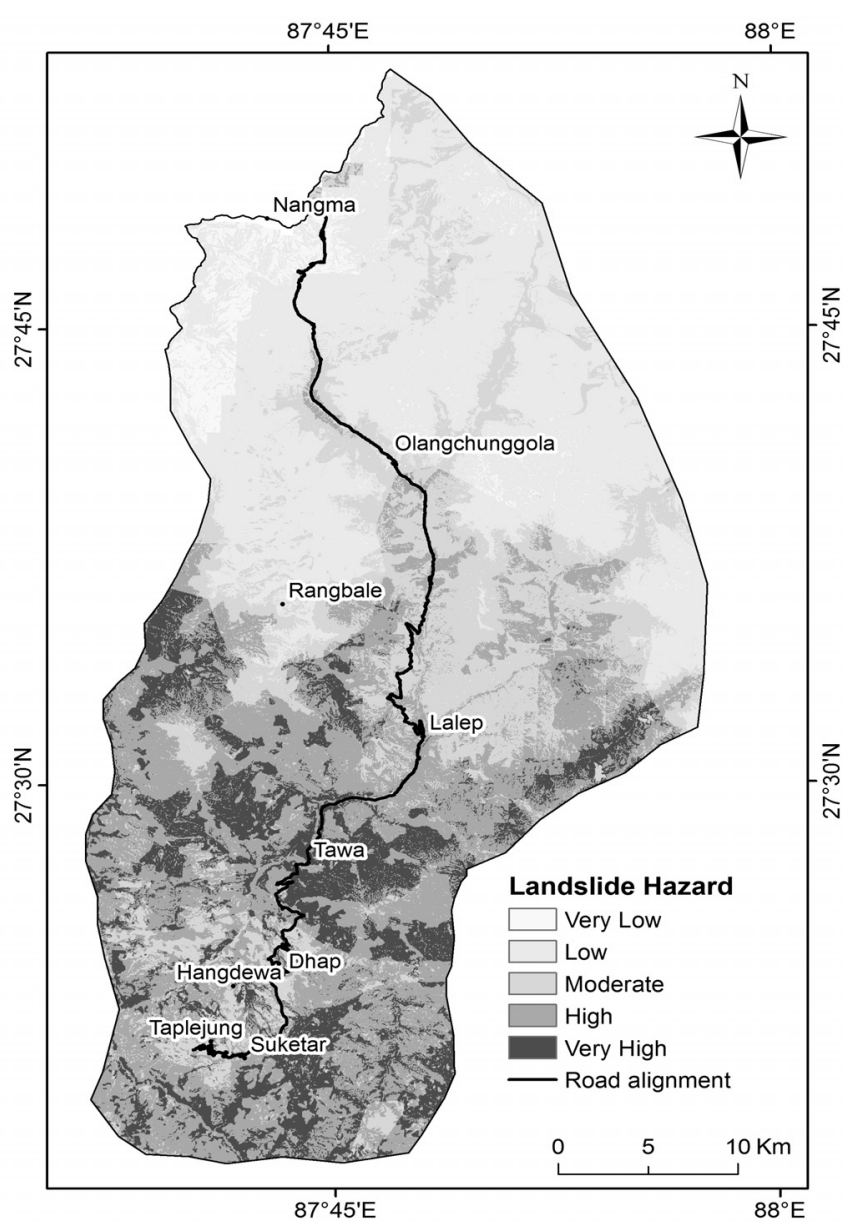

Fig. 16: Landslide hazard map of the study area.

The road section around Suketar village passes through high to very high landslide hazard class while further northward, up to Dhap village, it traverses through very low to moderate hazard class. The road stretch lying between Dhap to Lalep village falls within high to very high landslide hazard classes. However, the road lies on low to moderate landslide hazard class between the Lalep to Olangchunggola village. Most of the area between Olangchunggola and Nangma village is represented by very low to low hazard class with the exception of narrow zone with moderate hazard class north of Olangchunggola village. This condition is quite representing the real field condition where landslides have been observed in this zone.

\section{CONCLUSIONS}

Geohazard Assessment along the TaplejungOlangchunggola-Nangma road alignment has been carried out, principally through the use of remote sensing data interpretation and GIS analysis aided by the field study. The engineering geological investigations along the road corridor has been better assessed through the use of satellite imageries, GIS analysis of available data and field study. The landslide hazard map is helpful to broadly assess the geohazard condition along the road corridor, while the satellite image is especially useful to assess site specific hazard condition in detail.

The road alignment crosses different physiographic regions (Middle mountain, high mountain, high Himalaya) and the elevation reaches up to around 5,000 $\mathrm{m}$. Most of the road section traverses higher Himalayan region in the north, consisting of gneisses and quartzites. The lesser Himalayan rocks in the south of main central thrust is represented by low grade metamorphic rocks like phyllite, schist and quartzites. Mostly, the road passes through the vegetated area followed by barren area and agriculture area.

The area around the west of Taplejung is having numerous landslides, including the famous Hangdewa landslide. This active landslide area is avoided by the alignment, however, it may affect the road in future if mitigation measures are not adopted and the landslide further advances towards the upslope direction. In that case, it may also affect the Suketar airport. Taplejung to Lalep village is represented by moderate to very high landslide hazard zone. This road stretch is rather critical at various locations, which was also observed during the field study. The northern part of the road mostly passes through the low to moderate hazard zone. However, the road crosses some landslide area around Olangchunggola and northwards. The northern part of the road section is mainly threatened by the possible GLOF as there are many glacial lakes at the upper catchment in the eastern part. Likewise, possible rock fracturing due to frost action will result in rock disintegration followed by wedge failure and toppling.

The approach adopted in the present study to assess the geohazard along the road corridor could be equally applicable to other areas of Nepal where field accessibility is limited due to difficult terrain condition.

\section{ACKNOWLEDGEMENTS}

The author is thankful to V. Dangol and an anonymous reviewer for critical review of the manuscript that greatly helped to improved the article.

\section{REFERENCES}

Aleotti P., Chowdhury R., 1999. Landslide hazard assessment: Summary review and new perspective, Bulletin of Engineering Geology of the Environment, v. 58, pp. 21-44. Amatya, K. M and Jnawali, B. M., 1994. Geological map of Nepal, scale 1:1,000,000. Department of Mines and Geology (DMG).

Chung, C. J. F. and Fabbri, A. G, 2003. Validation of spatial prediction models for landslide hazard mapping. Natural Hazards, v. 30, pp. 451-472.

Dahal, R. K., Hasegawa, S., Nonomura A., Yamanaka, M., Dhakal S., Paudyal P., 2008. Predictive modelling of rainfallinduced landslide hazard in the Lesser Himalaya of Nepal based on weights-of-evidence, Geomorphology, v. 102 (3-4), pp. 496-510, doi:10.1016/j.geomorph.2008.05.041. Elsevier. 
Gerrard, AJ, Gardner, RAM, 2002. Relationships between landsliding and land use in the Likhu Khola drainage basin, Middle Hills, Nepal. Mt Res Dev, v. 22, pp. 48-55.

Glade, T., 2003. Landslide occurrence as a response to land use change: a review of evidence from New Zealand. Catena, v. 51, pp. 297-314.

Guzzetti F., Carrara A., Cardinali M. and Reichenbach P., 1999. Landslide hazard evaluation: a review of current techniques and their application in a multi-scale study, Geomorphology, v. 31, pp. 181-216.

Guzzetti, F., Galli, M., Reichenbach, P., Ardizzone, F., and Cardinali, M., 2006. Landslide hazard assessment in the Collazzone area, Umbria, Central Italy. Natural Hazards and Earth System Sciences, v. 6, pp. 115-131.

Hansen, A., 1984. Landslide hazard analysis. In: Brunsden, D. and Prior, D.B. (eds.) Slope instability, Wiley \& Sons, New York, pp. 523-602.

Hearn, G. J. and Hunt, T., 2011. Landslides and Mountain Roads. In Slope engineering for Mountain Roads (Ed. G. J. Hearn). Geological Society, London, Engineering Geology Special publication No. 24.

Hearn, G. J. and Hart, A. B., 2011. Geomorphological Mapping - Methods and Applications. Chapter Five - Geomorphological Contributions to Landslide Risk Assessment: Theory and Practice, Developments in Earth Surface Processes v. 15, pp. 107-148

Ho, K. K. S. and Lau, J. W. C., 2010. Learning from slope failures. Quaterly Journal of engineering Geology and Hydrogeology, v. 43, pp. 33-68.

Pathak, D, Gajurel, A. P. and Mool, P. K., 2010. Climate change impacts on hazards in the Eastern Himalayas; Climate change impact and vulnerability in the Eastern Himalayas - Technical report 5. Kathmandu: ICIMOD.

Pathak, D., 2014. Water Induced Disaster in Tamor River SubBasin, East Nepal, DWIDP Bulletin, Series XV, pp 6-11 (in press).

Petley, D. N., Hearn, G., Hart, A., Rosser, N., Dunning, S., Oven, K. and Mitchell W., 2007. Trends in landslide occurrence in Nepal. Natural Hazards, v. 43, issue 1, pages 23-44.

Remondo, J., González, A., Ramón, J., Cendrero, A., Fabbri, A. and Chung, C.-J.F., 2003. Validation of landslide susceptibility maps: examples and applications from a case study in Northern Spain. Natural Hazards, v. 30, pp. $437-449$.

Saha, A. K., Gupta, R. P., Sarkar, I., Arora, M. K. and Csaplovics, E., 2005. An approach for GIS-based statistical landslide susceptibility zonation - with a case study in the Himalayas, Landslides, v. 2, pp. 61-69.

Shrestha, S. B., Shrestha, J. N. and Sharma, S. R., 1984. Geological map of eastern Nepal, scale 1:250,000. Department of Mines and Geology (DMG).

Slaymaker, O. 2010. Mountain hazards. In: AlcantaraAyala, I. \& Goudie, A. (eds) Geomorphological Hazards and Disaster Prevention. Cambridge University Press, Cambridge, pp. 33-47.

Soeters, R. and van Westen, C.J., 1996. Slope instability recognition, analysis and zonation. In: Turner, A.K. and Schuster, R.L. (eds.) Landslide investigation and mitigation, National Research Council, Transportation Research Board Special Report 247, pp. 129-177.

Subramani, T. S. and Nanda Kumar, 2012. National Highway Alignment Using GIS. International Journal of Engineering Research and Applications (IJERA), v. 2, Issue 4, pp.427436.

van Westen, C.J., 1997. Statistical landslide hazard analysis. In: Application guide, ILWIS 2.1 for Windows. ITC, Enschede, The Netherlands, pp. 73-84.

van Westen, C.J., Rengers, N. and Soeters, R., 2003. Use of geomorphological information in indirect landslide susceptibility assessment. Natural Hazards, v. 30, pp. 399419.

Varnes, D.J., 1984. Landslide Hazard Zonation: a review of principles and practice, Commission on landslides of the IAEG, UNESCO, Natural Hazards, No. 3, 61p. 